\title{
Antibacterial Activity of Traditionally Used Plants against the Resistant Enteropathogenic Escherichia coli
}

Nitika Sharma, Anil Kumar Mishra, Ashok Kumar, Ashish Srivastava1, Kumarsen Gururaj, Desh Deepak Singh², Tarun Pal Singh, R.V.S. Pawaiya

10.18805/IJAR.B-4844

\begin{abstract}
Background: It is well known that the herbs have therapeutic efficacy against infectious agents including bacterial ones. In the current study, the antibacterial activities of methanolic extracts of nine herbs were evaluated against the resistant enteropathogenic E. coli (EPEC) using disc diffusion method.

Methods: Isolation and identification of E. coli and EPEC was done by standard bacteriological methods and PCR assays. Sensitivity of the EPEC isolates to antibiotics was determined by disc diffusion method. The methanolic extracts of the herbs were prepared and growth inhibition test was done by disc diffusion method. Minimum inhibitory concentration and minimum bactericidal concentration were determined by agar microdilution method.

Result: Out of 150 faecal samples, a total of $135 \mathrm{E}$. coli isolates were isolated and among them, a total of 36 isolates were identified as EPEC. EPEC isolates showed resistance to multiple antibiotics. The maximum mean inhibition zone of antibacterial effect against the resistant clinical isolates of EPEC was demonstrated by the methanolic extract of Holarrhaena antidysenterica $(19.16 \pm 0.76 \mathrm{~mm})$ followed by Acacia nilotica $(18.00 \pm 1.00 \mathrm{~mm})$ and Punica granatum $(16.67 \pm 1.53 \mathrm{~mm})$. This study validates that the said plants can be used as therapy against colibacillosis in neonatal goat kids.
\end{abstract}

Key words: Acacia nilotica, Colibacillosis, E. coli, Goat-kids, Holarrhaena antidysenterica, Neonatal diarrhoea, Punica granatum.

\section{INTRODUCTION}

Colibacillosis, commonly referred as E. coli scours, is the principal cause of neonatal diarrhoea in kids leading to heavy mortality (Smith and Sherman, 2009). Colibacillosis is caused by various pathotypes of $E$. coli and the most commonly associated pathotype is EPEC (Mishra et al., 2019).

For treatment of colibacillosis, various antimicrobial agents are routinely used (Constable, 2004). E. coli is rapidly gaining resistance against routinely used antibiotics due to their indiscriminate use (Voravuthikunchai et al., 2004). The latest generation of antibiotics are becoming out of reach for the poor goat keepers due to their high cost. Further, prolonged use of oral antibiotic therapy is potentially harmful to the intestinal mucosa of the neonatal goat kids resulting in malabsorption and diarrhoea (Farnsworth and Bunyapraphatsara, 1992). Associated side effects, development of antibiotic resistance and non-availability in rural and hilly regions are the other deterrence to use of antibiotics (Ma et al., 2021).

Plants have been used since time immemorial as growth promoters to treat a variety of diseases, ailments and disorders (Chakrabarti et al., 2021; Maqbool et al., 2021). Traditionally, rural and pastoral livestock owners of India have been using various plants to treat diarrhoea in ruminant neonates as non-specific antidiarrheal agents (Srivastava and Mondal, 2016; Laloo and Hemlatha, 2011; Srinivasan et al., 2001). The present study was designed to evaluate the antibacterial activity of nine plants namely Holarrhena antidysenterica, Acacia nilotica, Punica granatum, Gloriosa
Division of Animal Health, ICAR-Central Institute for Research on Goats, Makhdoom, Farah-281 122, Mathura, Uttar Pradesh, India. ${ }^{1}$ Department of Veterinary Clinical Medicine, Ethics and Jurisprudence, U.P. Pandit Deen Dayal Upadhyaya Veterinary University, Mathura-281 001, Uttar Pradesh, India.

${ }^{2}$ Department of Veterinary Pathology, College of Veterinary Sciences, Acharya Narendra Deva University of Agriculture and Technology, Ayodhya-224 229, Uttar Pradesh, India.

Corresponding Author: Anil Kumar Mishra, Division of Animal Health, ICAR-Central Institute for Research on Goats, Makhdoom, Farah-281 122, Mathura, Uttar Pradesh, India.

Email: anilmishradr@gmail.com

How to cite this article: Sharma, N., Mishra, A.K., Kumar, A., Srivastava, A., Gururaj, K., Singh, D.D., Singh, T.P. and Pawaiya, R.V.S. (2022). Antibacterial Activity of Traditionally Used Plants against the Resistant Enteropathogenic Escherichia coli. Indian Journal of Animal Research. DOI: 10.18805/IJAR.B-4844.

Submitted: 14-12-2021 Accepted: 10-01-2022 Online: 14-02-2022

suberba, Aegle marmelos, Cassia tora, Bambusa arundinacea, Psidium guajava and Murraya koenigii, which are commonly used by local livestock owners to treat diarrhoea in animals including goat-kids.

\section{MATERIALS AND METHODS}

The research work was conducted at ICAR-Central Institute for Research on Goats (ICAR-CIRG), Makhdoom, Farah, Mathura, UP, India during 2018-2020. Faecal samples were collected from 150 neonatal goat kids suffering from 
colibacillosis. Isolation and identification of $E$. coli was done as per the standard bacteriological method (Mishra et al., 2020; Mishra et al., 2017). The identification of EPEC was done by pathotype specific PCR targeting its bundle forming pilus A (bfpA) gene as used by Lopez et al. (2003). Sensitivity of all isolates of EPEC to the antibiotics was determined by disc diffusion method of Kirby et al. (1968). The details of the antibiotics used in the study are given in Table 1.

The existing scientific literature on the herbs, indigenous traditional knowledge (ITK), availability of the herbs in the particular area and traditional beliefs of the rural livestock farmers aretaken into consideration for the selection and identification of the medicinal herbs (Srivastava and Mondal, 2016). On this basis, nine herbs namely bark of Holarrhena antidysenterica, bark of Acacia nilotica, rind of Punica granatum, leaves of Gloriosa suberba, semi ripe fruit of Aegle marmelos, leaves of Cassia tora, leaves of Bambusa arundinacea, leaves of Murraya koenigiiand and leaves of Psidium guajava were selected for the study. The plants were authenticated on taxonomical basis by the Faculty of Department of Botany, Babu Shivnath Aggarwal (BSA) College, Mathura, Uttar-Pradesh, India. The methanolic extracts of the plants were prepared as per the method recommended by Paech and Tracy (1956).

A standard disc diffusion method described by Bauer et al., (1966) was used for assessing the antibacterial efficacy of the selected plant materials against the resistant EPEC. Methanolic extracts of the herbal plants were screened for antibacterial property and compared with ciprofloxacin (HiMedia ${ }^{\circledR}$ discs, $6 \mathrm{~mm}$ ) as a standard antibiotic against the resistant EPEC as described by Prasanth et al., (2001). Sterile filter paper discs of $6 \mathrm{~mm}$ diameter (Hi Media ${ }^{\circledR}$ ) were soaked with $20 \mu \mathrm{l}$ of extract diluted in $1 \%$ Tween-20 solution in three different concentrations (100, 200 and 400 $\mathrm{mg} / \mathrm{ml}$ ). Three discs were impregnated with $2 \mathrm{mg}, 4 \mathrm{mg}$ and $8 \mathrm{mg}$ of the each plant extract, respectively and their antibacterial activity was evaluated by measuring the diameter of inhibition zone as per the method described by Srivastava and Mondal (2016).

Minimum inhibitory concentration (MIC) of the methanolic herbal extract revealing the highest antibacterial activity during in vitro screening was measured using broth dilution method (Doughari, 2006). Further, the minimum bactericidal concentration (MBC) of the methanolic herbal extract was assessed as per the method described by Doughari (2006).

Statistical analysis of the data obtained was done by one way analysis of variance (ANOVA) at $95 \%$ level of significance and results are displayed as Mean \pm S.E (Snedecor and Cochram, 1994).

\section{RESULTS AND DISCUSSION}

Isolation, characterisation and confirmatory identification of enteropathogenic $E$. coli

A total of 135 isolates of $E$. coli were recovered from 150 faecal samples from diarrhoeic neonatal goat-kids (Fig 1).
Pathotype specific PCR targeting bfpA resulted in to a single amplicon of $324 \mathrm{bp}$, which indicates confirmatory identification of EPEC as illustrated in Fig 2. In the current study, EPEC was selected as target pathogen, because it is the most common cause of colibacillosis in neonatal goatkids as reported by Mishra et al. (2019). The pattern of antibiotic resistance shown by EPEC isolates indicated their multi-antibiotic resistant status (Table 1).

\section{Antibacterial efficacy of the selected plants against the resistant EPEC}

Among the 9 methanolic extracts evaluated for their antibacterial activity, only extracts of Holarrhena

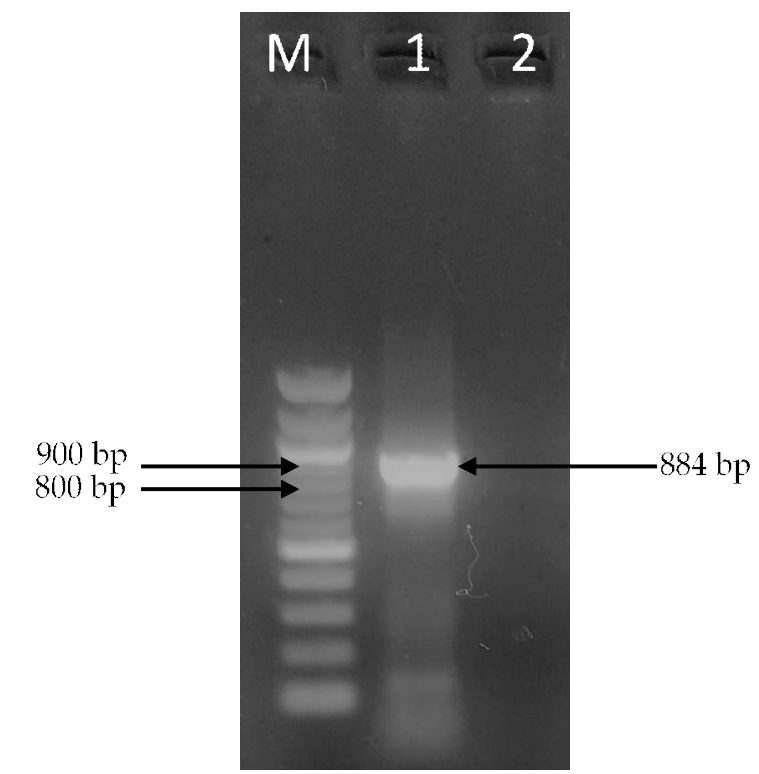

Fig 1: Detection of $E$. coli by PCR.

Lane M: Molecular weight marker

Lane 1: Amplified PCR products

Lane 2: Negative sample

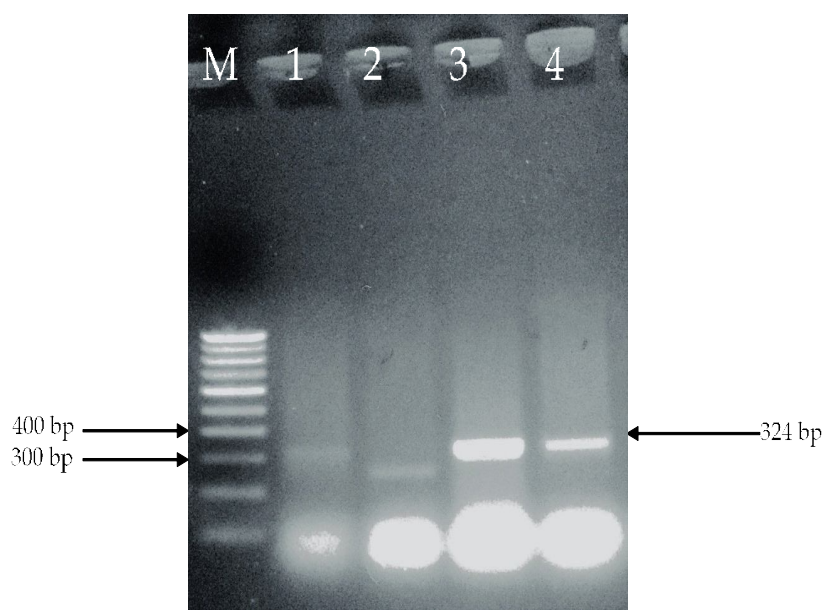

Fig 2: Detection of EPEC by PCR.

Lane M: Molecular weight marker.

Lane 1, 3, 4: Amplified PCR products.

Lane 2: Negative sample. 
antidysenterica (bark), Acacia nilotica (bark), Punica granatum (rind), Gloriosa suberba (leaves) and Aegle marmelos (fruit) showed antibacterial activity against antibiotic resistant clinical isolates of EPEC (Table 2). The leaves of other 4 medicinal plants viz. Cassia tora, Bambusa arundinacea, Murraya koenigii and Psidium guajava did not exhibit any antibacterial potential against the resistant EPEC isolates (Table 2). The maximum mean inhibition zone of antibacterial effect was demonstrated by the methanolic extract of Holarrhena antidysenterica $(19.16 \pm 0.76 \mathrm{~mm})$ followed by Acacia nilotica $(18.00 \pm 1.00 \mathrm{~mm}$ ) and Punica granatum (16.67 $\pm 1.53 \mathrm{~mm}$ ) (Table 2). Standard antibiotic, i.e., ciprofloxacin produced consistent inhibition zone of 32 $\mathrm{mm}$ and served as positive control, whereas discs impregnated with aqueous tween-20 solution (1\%) didn't exhibit any antibacterial activity in the form of inhibition zone and served as negative control.

The antibacterial property of plant extracts varies with type of solvents used (Rani and Khullar, 2004). Methanolic or acetone extracts of plants possessing antimicrobial potential exhibited much more pronounced activity in comparison to ethanol or aqueous extract against a variety of pathogenic microbes like E. coli (Eloff, 1998). Taking these studies into the consideration, the methanolic extracts of the herbs were used for evaluation of their antimicrobial properties.

During in vitro screening of plant extracts for antibacterial property, Holarrhena antidysenterica exhibited maximum zone of inhibition and therefore, it was considered for further evaluation in terms of MIC and MBC. After $24 \mathrm{hr}$ of incubation, turbidity appeared in tubes containing the extract @ 0.5 and $1.0 \mathrm{mg} / \mathrm{ml}$, whereas no growth was observed in all the other tubes (containing Holarrhena antidysenterica extract @ 2,3,4,5,6,7,8,9 and $10 \mathrm{mg} / \mathrm{ml}$ ) on visual inspection. Lush growth was observed in the tube not containing any amount of the extract. On the basis of the above finding, the MIC of Holarrhena antidysenterica extract was considered to be $2 \mathrm{mg} / \mathrm{ml}$. During MBC trial, good growth was observed on nutrient agar plates streaked with the inoculum taken from MIC tubes having Holarrhena antidysenterica extract @ 0.5 and $1.0 \mathrm{mg} / \mathrm{ml}$, whereas significant reduction in bacterial growth was seen at $2 \mathrm{mg} /$ $\mathrm{ml}$ (MIC value). No bacterial growth occurred at concentrations of $3-10 \mathrm{mg} / \mathrm{ml}$. Hence, MBC of Holarrhena antidysenterica extract was considered to be $3 \mathrm{mg} / \mathrm{ml}$.

The antibacterial activity of plant extracts can be attributed to the presence of broad-spectrum antimicrobial compounds in them (Marjorie, 1999). Methanolic extracts of Holarrhena antidysenterica, Acacia nilotica, Punica granatum and Gloriosa suberba possess high amount of tannins and phenolic compounds (Senthilkumar, 2013; Kavitha and Niranjali, 2009; Misar et al., 2007; Prasanth et al., 2001). Tannins possess antimicrobial potential owing to their astringent activity and capability to inactivate the microbial adhesins, enzymes, cell envelope transport proteins etc. (Cowan, 1999). Like synthetic phenols compounds, tannins adversely affect the integrity of bacterial cell membranes. Tannins chelate the metal ions such as

Table 1: Antibiotic Susceptibility of the E. coli isolates $(n=36)$ obtained from the diarrhoeic neonatal goat-kids.

\begin{tabular}{|c|c|c|c|c|}
\hline \multirow{2}{*}{ Antimicrobial agent } & \multirow{2}{*}{ Concentration $(\mu \mathrm{g})$} & \multicolumn{3}{|c|}{ Extent of the susceptibility } \\
\hline & & Susceptible (\%) & Intermediate (\%) & Resistant (\%) \\
\hline Amikacin & 10 & $94.44(34 / 36)$ & $2.77(1 / 36)$ & $2.77(1 / 36)$ \\
\hline Ampicillin & 10 & $16.6(6 / 36)$ & $13.88(5 / 36)$ & $69.44(25 / 36)$ \\
\hline Amoxicillin & 10 & $30.55(11 / 36)$ & $2.77(1 / 36)$ & $66.66(24 / 36)$ \\
\hline Amoxy-Clavulinic acid & 10 & $8.33(3 / 36)$ & $19.44(7 / 36)$ & $63.88(23 / 36)$ \\
\hline Colistin & 50 & $83.33(30 / 36)$ & $16.66(6 / 36)$ & $0(0 / 36)$ \\
\hline Ceftriaxone & 10 & $55.55(20 / 36)$ & $13.88(5 / 36)$ & $30.55(11 / 36)$ \\
\hline Cephadroxil & 30 & $61.66(22 / 36)$ & $13.88(5 / 36)$ & $25(9 / 36)$ \\
\hline Cephalexin & 30 & $66.66(24 / 36)$ & $8.33(3 / 36)$ & $25(9 / 36)$ \\
\hline Chloramphenicol & 10 & $50(18 / 36)$ & $30.55(11 / 36)$ & $19.44(7 / 36)$ \\
\hline Ciprofloxacin & 10 & $41.66(15 / 36)$ & $30.55(11 / 36)$ & $27.77(10 / 36)$ \\
\hline Co-Trimoxazole & 25 & $5.55(2 / 36)$ & $5.55(2 / 36)$ & $88.88(32 / 36)$ \\
\hline Enrofloxacin & 10 & $36.11(13 / 36)$ & $11.11(4 / 36)$ & $52.55(19 / 36)$ \\
\hline Erythromycin & 10 & $27.77(10 / 36)$ & $33.33(12 / 36)$ & $38.88(14 / 36)$ \\
\hline Furazolidone & 100 & $100(36 / 36)$ & $0(0 / 36)$ & $0(0 / 36)$ \\
\hline Gentamicin & 10 & $52.77(19 / 36)$ & $19.44(7 / 36)$ & $27.77(10 / 36)$ \\
\hline Norfloxacin & 10 & $52.77(19 / 36)$ & $11.11(4 / 36)$ & $36.11(13 / 36)$ \\
\hline Novobiocin & 5 & $50(18 / 36)$ & $13.88(5 / 36)$ & $36.11(13 / 36)$ \\
\hline Oxytetracycline & 30 & $38.88(14 / 36)$ & $5.55(2 / 36)$ & $55.55(20 / 36)$ \\
\hline Streptomycin & 10 & $16.66(6 / 36)$ & $16.66(6 / 36)$ & $66.66(24 / 36)$ \\
\hline Sulfadiazine & 100 & $2.77(1 / 36)$ & $5.55(2 / 36)$ & $91.66(33 / 36)$ \\
\hline Tobramycin & 10 & $47.22(17 / 36)$ & $16.66(6 / 36)$ & $36.11(13 / 36)$ \\
\hline
\end{tabular}


Antibacterial Activity of Traditionally Used Plants against the Resistant Enteropathogenic Escherichia coli

Table 2: In vitro antibacterial activity of the plant extracts against enteropathogenic $E$. coli.

\begin{tabular}{|c|c|c|c|c|c|c|c|c|c|}
\hline $\begin{array}{l}\text { Treatment } \\
(n=3)\end{array}$ & $\begin{array}{c}\text { Holarrhaena } \\
\text { antidysenterica }\end{array}$ & $\begin{array}{l}\text { Acacia } \\
\text { nilotica }\end{array}$ & $\begin{array}{c}\text { Punica } \\
\text { granatum }\end{array}$ & $\begin{array}{l}\text { Gloriosa } \\
\text { superba }\end{array}$ & $\begin{array}{c}\text { Aegle } \\
\text { marmelos }\end{array}$ & $\begin{array}{c}\text { Cassia } \\
\text { tora }\end{array}$ & $\begin{array}{c}\text { Bambusa } \\
\text { arundinacea }\end{array}$ & $\begin{array}{l}\text { Murraya } \\
\text { koenigii }\end{array}$ & $\begin{array}{l}\text { Psidium } \\
\text { guajava }\end{array}$ \\
\hline $2 \mathrm{mg} / \mathrm{disc}$ & $15.53 \pm 0.55^{\mathrm{aDE} *}$ & $13.50 \pm 0.50^{\mathrm{ac}}$ & $14.13 \pm 1.03^{\mathrm{ac}}$ & $11.33 \pm 1.53^{\mathrm{aB}}$ & $9.00 \pm 1.00^{\mathrm{aB}}$ & - & - & - & - \\
\hline $4 \mathrm{mg} / \mathrm{disc}$ & $16.93 \pm 1.01^{\mathrm{abD}}$ & $16.17 \pm 1.04^{\mathrm{bD}}$ & $15.50 \pm 1.32^{\mathrm{aCD}}$ & $13.97 \pm 1.62^{\mathrm{ac}}$ & $11.00 \pm 1.00^{\mathrm{bB}}$ & - & - & - & - \\
\hline $8 \mathrm{mg} / \mathrm{disc}$ & $19.16 \pm 0.76^{\mathrm{bE}}$ & $18.00 \pm 1.00^{\mathrm{CE}}$ & $16.67 \pm 1.53^{\mathrm{aD}}$ & $14.00 \pm 2.00^{\mathrm{aCD}}$ & $11.37 \pm 0.78^{\mathrm{bB}}$ & - & - & - & - \\
\hline
\end{tabular}

*Mean with different superscripts in a row (capital letters) and column (small letters) differs significantly $(p<0.05)$.

iron and form a complex, which results in antimicrobial activity through iron depletion (Scalbert, 1991). Alkaloids present in the methanolic extract of Holarrhena antidysenterica interfere and reduce the initial bacterial adhesion to intact epithelial cells and it may exert an antiadherence effect against the pathogenesis of enteropathogenic $\mathrm{E}$. coli in the host epithelial cells (Kavitha and Niranjali, 2009).

In the present study, the methanolic extract of semiripe fruit of Aegle marmelos showed antibacterial activity against the multi-drug resistant EPEC. Similar results have also been reported regarding the antibacterial potential of Aegle marmelos against a variety of enteropathogenic bacteria in previous studies (Mazumder et al., 2006). In our study, the methanolic extract of the leaves of Psidium guajava did not exhibit any antibacterial potential against multi-drug resisitant EPEC isolates. However, in the previous reports, the antimicrobial potential of Psidium guajava against enteropathogenic $E$. coli isolates from calves was confirmed (Srivastava and Mondal, 2016). This variation could be due to differences of genotypes amongst EPEC isolates and herbal plants.

It has been reported earlier that ethanolic extract of Holarrhena antidysenterica bark had MIC value of $2 \mathrm{mg} / \mathrm{ml}$ and $M B C$ value of $3 \mathrm{mg} / \mathrm{ml}$ against $E$. coli (Singh et al., 2016). In the present study, methanolic extract of Holarrhena antidysenterica bark exhibited a MIC value of $2 \mathrm{mg} / \mathrm{ml}$ and a $M B C$ value of $3 \mathrm{mg} / \mathrm{ml}$ against the multi-drug resistant EPEC. Similarities in the results of present study and previous studies may be due to several factors. The most important one is that the methodology as well as the pathogen chosen for the study is same viz. diarrhoeagenic $E$. coli.

Similar to our results, exploratory studies carried out by Misar et al., (2007) in mice also revealed presence of significant antidiarrheal activity in the methanolic extract of Acacia nilotica. Its aqueous extract was found effective in treating biofilm forming and multidrug resistant uropathogenic E. coli by Elamary et al., (2020). Several studies support the ethnomedicinal use of Acacia nilotica bark for the treatment of diarrhoea and other ailments (Misar et al., 2007).

Though, various reports have linked the antimicrobial potential of plants to the presence of tannins in them (Girard and Bee, 2020) but in the present study, no antimicrobial activity was observed in the methanolic extracts of Bambusa arudinacea and Psidium guajava leaves, which contain significant amount of tannins. Hence, further detailed phytochemical evaluation of plant extracts exhibiting significant antibacterial potential is warranted.

It is quite obvious from the existing scientific literature, antibacterial potential of different plants tested, could not be endorsed entirely to presence of any singular chemical constituent (Ozcelik et al., 2006; Marjorie, 1999). Differences in the efficacy and specificity exist among the different types of phytochemicals present in a plant or its extract. These differences are attributed to the concentration of phytochemicals and chemical structure. Further investigations are needed to determine the optimal combinations of phytochemicals and the most suitable and cost-effective manner to deliver them (Girard and Bee, 2020). Certain disagreements between in vitro and in vivo results could be explained by the metabolism of phytochemicals along the intestinal tract. Whether and which phytochemicals and their metabolites remain active in the intestine warrant further research. There is a necessity to further explore different phytochemical components of the plant extract in terms of their mode of action and possible interactions responsible for their antibacterial potential.

\section{CONCLUSION}

This study validates the use of Holarrhena antidysenterica, Acacia nilotica, Punica granatum, Gloriosa suberba and Aegle marmelos as sole or adjunct therapy against colibacillosis in neonatal goat-kids.

\section{ACKNOWLEDGEMENT}

The authors are thankful to the Director, ICAR-Central Institute for Research on Goats, Makhdoom for providing necessary facilities as well as financial support to conduct the study.

Conflict of interest: None.

\section{REFERENCES}

Bauer, A.W., Kirby, W.M.M., Sherris, J.C., Turk, M. (1966). Antibiotic susceptibility testing by a standardized single disc method. Am. J. Clin. Path. 45: 493-496.

Chakrabarti, A., Sarkar, P.K., Kumar, P.R., Yadav, V.K., Naik, S. K., Jha, B.K., Dey, A., Bhatt, B. P. (2021). Use of flower of Spilanthes paniculata Wall. ex DC as growth promoter in Divyan Red Poultry Birds. Indian Journal of Animal Research. 55: 669-673.

Constable, P.D. (2004). Antimicrobial use in the treatment of calf diarrhea. J. Vet. Intern. Med. 18: 8-17. 
Cowan, M.M. (1999). Plant Products as Antimicrobial Agents. Clin. Microbiol. Rev. 12: 564-582.

Doughari, J.H. (2006). Antimicrobial activity of Tamarindus indica L. Trop.J. Pharm. Res. 5:597-603.

Elamary, R.B., Albarakaty, F.M., Salem, W.M. (2020). Efficacy of Acacia nilotica aqueous extract in treating biofilm-forming and multidrug resistant uropathogens isolated from patients with UTI syndrome. Sci. Rep. 10: 11125.

Eloff, J.N. (1998). Which extractant should be used for the screening and isolation of antimicrobial components from plants? J. Ethnopharmacol. 60: 1-8.

Farnsworth, N.R. and Bunyapraphatsara, N. (1992). Thai Medicinal Plants Recommended for Primary Health Care Systems, Bangkok, Prachachon. pp 267-396.

Girard, M. and Bee, G. (2020). Invited review: Tannins as a potential alternative to antibiotics to prevent coliform diarrhea in weaned pigs. Animal. 14: 95-107.

Kavitha, D. and Niranjali, S. (2012). Inhibition of enteropathogenic Escherichia coli adhesion on host epithelial cells by Holarrhena antidysenterica (L.) Wall. Phytother Res. 23: 1229-36.

Kirby, W.M.N., Bauer, A.W., Shernis, J.C, Turch, M. (1968). Antibiotic sterility testing by standard single dose method. Am. J. Clin. Pathol. 45:493-496.

Laloo, D. and Hemalatha, S. (2011). Ethnomedicinal plants used for diarrhea by tribals of Meghalaya, Northeast India. Pharmacogn. Rev. 5: 147-154.

Landers, T.F., Cohen, B., Wittum, T.E., Larson, E.L. (2012). A review of antibiotic use in food animals: perspective, policy and potential. Public health reports (Washington, D.C.: 1974). 127: 4-22.

López, S.C., Cerna, J.F., Villegas, S.N., Thompson, R., Velazquez, F.R., Torres, J., Estrada-Garcia, T. (2003). Single multiplex polymerase chain reaction to detect diverse loci associated with diarrheagenic Escherichia coli. Emerg. Infect. Dis., 9: 127.

Ma, F., Xu, S., Tang, Z., Li, Z., Zhang, L. (2021). Use of antimicrobials in food animals and impact of transmission of antimicrobial resistance on humans. Biosafety and Health. 3: 32-38.

Maqbool, S., Ullah, N., Zaman, A., Akbar, A., S. Saima, Nawaz, H., Samad, N., Ullah, R., Bari, A., Ali, S.S. (2021). Phytochemical screening, in-vitro and in-vivo anti-diabetic activity of Nelumbo nucifera leaves against alloxan-induced diabetic rabbits. Indian Journal of Animal Research. 55: 78-83.

Marjorie, M.C. (1999). Plant products as antimicrobial agents. Clin Microbiol Rev. 12: 564-582.

Mazumder, R., Bhattacharya, S., Mazumder, A., Pattnaik, A.K., Tiwary, P.M., Chaudhary, S. (2006). Antidiarrhoeal evaluation of Aegle marmelos (Correa) Linn. root extract. Phytother. Res. 20: 82-84.
Misar, A., Bahgat, R., Mujumdar, A. (2007). Antidiarrhoeal activity of Acacia nilotica Willd. bark methanol extract. Hindustan Antibiotics Bulletin. 49-50: 14-20.

Mishra, A.K., Singh, D.D., Gururaj, K., Gupta, G., Sharma, N., Kumar, N., Nayakvadi S., Paul, S. (2017). UspA Gene based characterization of Escherichia coli strains Isolated from different disease conditions in goats. J. Ani. Res. 7: $1-6$.

Mishra, A.K., Singh, D.D., Gururaj, K., Kumar, A., Dixit, A., Shrama, N., Gupta, G., Yadav, S. (2019). Molecular characterization of diarrhoegenic Escherichia coli isolated from neonatal goat-kids. J. Ani. Res. 9: 1-9.

Mishra, A.K., Singh, D.D., Kumar, N., Kumarsen, G., Paul, S., Kumar, A. (2020). Role of bacterial and parasitic pathogens in occurrence of neonatal diarrhoea in goat-kids. J. Anim. Res. 10: 389-395.

Ozcelik, B., Orhan, I., Toker, G. (2006). Antiviral and antimicrobial assessment of some selected flavonoids. Z. Naturforsch. 61: $632-638$.

Paech, K. and Tracy, M.V. (1956). Modern method of plant analysis Vol. 1 Berlin : Springer Verlog.

Prashanth, D., Asha, M.K., Amit, A. (2001). Antibacterial activity of Punica granatum, Fitoterapia. 72: 171-173.

Rani, P. and Khullar, N. (2004). Antimicrobial evaluation of some medicinal plants for their anti - enteric potential against multi-drug resistant Salmonella typhi. Phytother. Res. 18: $670-673$.

Scalbert, A. (1991). Antimicrobial properties of tannins. Phytochemistry. 30: $3875-3883$.

Senthilkumar, M. (2013). Phytochemical screening of Gloriosa superba L. - from different geographical positions. Inter national Journal of Scientific and Research Publications. 3: $1-5$.

Singh, M., Gupta,V.K., Mondal, D.B., Shakya M., Sharma, D.K. (2016). Evaluation of antibacterial and therapeutic potential of Holarrhena antidysenterica bark extract in E.coli calf diarrhea. Int. J. Adv. Res. 4: 1334-1339.

Smith, M.C. and Sherman, D.M. (2009). Wiley-Blackwell Publication, lowa (USA), $2^{\text {nd }}$ Edition. Goat Medicine.

Snedecor, G.W. and Cochram, W.G. (1994). Statistical Methods, $8^{\text {th }}$ edn. lowa state university press, USA.

Srinivasan, D., Perumalsamy, L.P., Nathan, S., Sures, T. (2001). Antimicrobial activity of certain Indian medicinal plants used in folkloric medicine. J. Ethnopharm. 94: 217-222.

Srivastava, A. and Mondal, D.B. (2016). Comparative evaluation of antibacterial efficacy of plants traditionally used as antidiarrheal against enteropathogenic Escherichia coli. Indian J. Anim. Res. 50: 80-84.

Voravuthikunchai. S.P., Lortheeranuwat, A., Ninrprom, T., Popaya, W., Pongpaichit, S., Supawita, T. (2004). Effective medicinal plants against enterohaemorrhagic Escherichia coli O157:H7. J. Ethnopharmacol. 94: 49-54. 